\title{
PENGARUH DINING EXPERIENCE TERHADAP KEPUASAN KONSUMEN DAN REVISIT INTENTION DI RESTORAN KOREA DI SURABAYA PADA ERA NEW NORMAL
}

\author{
Angela Virginia Mulyono ${ }^{1}$, Bryant Septiano ${ }^{2}$, Adriana Aprilia ${ }^{3 *}$ \\ ${ }_{1,2,3}$ Program Manajemen Perhotelan, Program Studi Manajemen, Fakultas Bisnis dan Ekonomi, \\ Universitas Kristen Petra,Jl. Siwalankerto $121-131$, Surabaya \\ Email: 1angelamulyono@gmail.com; ${ }^{2}$ bryantseptiano@gmail.com; ${ }^{3}$ aprilia@petra.ac.id \\ *Penulis korespondensi
}

\begin{abstract}
Abstrak
Penelitian ini bertujuan untuk menganalisa pengaruh kualitas makanan, kualitas layanan, dan lingkungan fisik yang merupakan dimensi dari dining experience terhadap kepuasan konsumen dan revisit intention konsumen di restoran Korea di Surabaya pada era new normal. Kuesioner disebarkan terhadap 100 responden melalui metode pengambilan sampel purposive sampling. Analisa data menggunakan smart PLS yang pernah makan di restoran Korea di Surabaya (Juli 2020 - Oktober 2020). Hasil penelitian menunjukkan bahwa kualitas makanan, kualitas layanan dan lingkungan fisik berpengaruh positif dan signifikan terhadap kepuasan konsumen namun tidak signifikan terhadap revisit intention. Selain itu kepuasan konsumen juga berpengaruh positif dan signifikan terhadap revisit intention.
\end{abstract}

Kata kunci: Dining experience; kualitas makanan; kualitas layanan; lingkungan fisik; kepuasan konsumen; revisit intention; new normal.

\begin{abstract}
This study aims to analyze the influence of food quality, service quality, and physical environment which are dimensions of dining experience on consumer satisfaction and consumer revisit intention at Korean restaurants in Surabaya during the new normal era. Quesionnaires were spread to 100 respondents. Data were analyzed with the smart PLS software. The results showed that food quality, service quality, and physical environment had a positive and significant effect on consumer satisfaction but not significant on revisit intention. In addition, customer satisfaction also has a positive and significant effect on revisit intention.
\end{abstract}

Keywords: Dining experience; food quality; service quality; physical environment; customer satisfaction; revisit intention; new normal.

\section{PENDAHULUAN}

Pada awal 2020, usaha kafe dan restoran mendapat dampak adanya pandemi COVID-19 yang hingga saat ini telah menyebar di lebih dari 200 negara di seluruh dunia. Seluruh kegiatan ekonomipun menjadi terganggu dan terhambat khususnya di industri Food and Beverage saat pemerintah menerapkan Pembatasan Sosial Berskala Besar (PSBB). Setelah PSBB berakhir, Surabaya memasuki era new normal. Restoran yang beroperasi saat new normal wajib menerapkan protokol kesehatan sesuai yang tertera pada peraturan Walikota Surabaya Nomor 28 Tahun 2020 tentang tatanan normal baru pada kondisi pandemi Corona Virus Disease 2019 (COVID-19) di kota Surabaya (Peraturan Walikota Surabaya, 2020). Sejak Juli 2020 sudah ada peningkatan omset pada bisnis kafe dan restoran. Survei dari Mandiri Institute adanya peningkatan kunjungan konsumen restoran di Surabaya pada era new normal, ada kenaikan dari $37 \%$ pada bulan Juli menjadi 55\% pada bulan Agustus.

Popularitas dan pertumbuhan kuliner Korea inipun tidak lepas dari pengaruh Korean Wave atau Hallyu di kalangan masyarakat terutama remaja. Menurut Haryani (2012), Hallyu merupakan sebutan penyebaran budaya pop Korea secara mendunia. Penyebaran budaya pop Korea ini membuat para penggemarnya ingin mempelajari dan mengikuti kebudayaan Korea mulai dari musik (Korean Pop), drama, film, gaya berbusana, kosmetik, hingga kuliner (Hasanah dan Rencidiptya, 2020).

Jae Su Kim, President Korea Agro-Fisheries and Food Trade Corporation mengatakan bahwa saat ini kuliner Korea banyak digemari berbagai bangsa karena rasa dan tampilannya yang unik, terbuat dari bahan-bahan segar yang bermanfaat untuk kesehatan 
(Bahurekso, 2015). Menurut survei yang dilakukan oleh Statista tahun 2019 terhadap 500 responden dari usia 15 - 59 tahun, sebanyak $60 \%$ responden setuju bahwa kuliner Korea di Indonesia sangat populer.

Restoran etnik seperti restoran Korea menawarkan dining experience yang berbeda. Hal ini dikarenakan konsumen dapat merasakan pengalaman suatu budaya baru dan unik yang eksotis dari kuliner yang disajikan dengan cita rasa yang otentik, serta suasana (atmosphere) restoran yang ditampilkan semirip mungkin dengan budaya Korea (Ha dan Jang, 2010). Dining experience merupakan hasil evaluasi konsumen atas pengalaman bersantap di suatu restoran. Restoran yang menawarkan keunikan menu dengan harga yang wajar namun juga yang menawarkan pengalaman yang mengesankan melalui lingkungan fisik dan pelayanan yang baik, akan menjadi pilihan konsumen saat ini. Para pebisnis sangat menyadari bahwa saat ini fungsi restoran tidak hanya untuk menjual makanan dan minuman saja tetapi juga menjual suasana, pelayanan, dan pengalaman bagi konsumennya. Untuk dapat bertahan di industri yang kompetitif ini maka restoran harus mampu memberikan dining experience yang komprehensif dan mengesankan (Canny, 2014).

Penelitian terdahulu oleh Canny (2014) mengungkapkan bahwa untuk dapat memaksimalkan dining experience bagi konsumen ada 3 dimensi yang harus diperhatikan yakni kualitas makanan, kualitas layanan dan lingkungan fisik. Kualitas makanan merupakan kelayakan suatu makanan untuk dikonsumsi (Canny, 2014). Sedangkan kualitas layanan merupakan pengukuran subjektif oleh konsumen dengan membandingkan ekspektasi dan realita setelah menerima layanan. Lingkungan fisik merupakan desain suatu tempat yang dirancang agar dapat memberikan efek emosional konsumen untuk menumbuhkan pembelian (Mannan, Chowdhury, Sarker \& Amir, 2019).

Ketika konsumen mendapatkan dining experience yang baik maka timbul kepuasan atas pengalaman bersantapnya. Menurut Marinkovic, Senic, Ivkov, Dimitrovski dan Bjelic (2014) kepuasan adalah reaksi emosional yang timbul ketika kinerja suatu produk atau jasa melebihi ekspektasi konsumen. Semakin banyak konsumen yang puas maka semakin besar peluang dari suatu bisnis untuk mencapai kesuksesan karena konsumen yang puas mempunyai kecenderungan akan berkunjung kembali. Ryu et al. (2012) menyatakan bahwa restoran yang mampu memberikan dining experience dengan baik akan menciptakan kepuasan konsumen yang akan menumbuhkan revisit intention.

Revisit intention mengacu pada keinginan konsumen untuk melakukan pembelian kembali dan keinginan untuk merekomendasikan produk ataupun jasa tertentu pada orang lain (Yong, Siang, Lok dan Kuan, 2013). Merujuk dari pernyataan di atas, ada berbagai faktor yang akan menentukan konsumen dalam memilih untuk kembali ke restoran yang pernah dikunjungi. Kualitas makanan, kualitas layanan serta lingkungan fisik menjadi pertimbangan apakah sebuah restoran layak untuk dikunjungi kembali.

Penulis melakukan wawancara terhadap 10 responden untuk mengetahui tanggapan responden mengenai dining experience di restoran Korea di Surabaya saat era new normal dan apakah responden merasa puas serta mau untuk datang kembali. Hasilnya responden merasa saat makan langsung di era new normal berbeda dengan sebelum new normal karena adanya protokol kesehatan yang harus dipatuhi. Meski demikian mayoritas responden merasa senang karena restoran Korea yang dikunjungi sangat mematuhi protokol kesehatan. Selain menyajikan makanan yang enak dengan porsi yang banyak ekspektasi responden atas higienitas dan pelayanan restoran Korea saat new normal dijalankan dengan baik yang membuat responden merasa aman. Hal lain yang membuat responden ingin mengunjungi restoran Korea karena adanya rasa jenuh makan dan masak sendiri di rumah selama pandemi ini sehingga responden ingin merasakan suasana restoran. Dari wawancara ini 7 dari 10 responden merasa puas dan bersedia untuk melakukan kunjungan kembali.

Merujuk pada penelitian terdahulu oleh Canny (2014) namun pada penelitian kali ini hanya mengukur pengaruh secara langsung dari variabel dining experience terhadap kepuasan dan revisit intention. Berbeda dengan penelitan Canny (2014) yang mengukur pula pengaruh secara tidak langsung variabel dining experience terhadap revisit intention melalui kepuasan konsumen sebagai variabel moderator. Maka berdasarkan fenomena di atas, penulis ingin mengukur pengaruh dining experience dalam menciptakan kepuasan konsumen serta mengukur lebih dalam terkait dining experience dapat menumbuhkan revisit intention konsumen pada restoran Korea di Surabaya terutama pada era new normal saat ini.

\section{TINJAUAN PUSTAKA}

\section{Dining Experience}

Menurut Kotschevar dan Withrow (2008) dining experience mengacu pada serangkaian pengalaman baik berwujud maupun tidak berwujud yang dirasakan oleh konsumen saat makan di suatu restoran. Keseluruhan dining experience dapat diperhitungkan 
dari perasaan-perasaan yang timbul saat konsumen datang ke restoran sampai meninggalkan restoran. Canny (2014) menyatakan untuk dapat mengukur dining experience yang berkesan terdapat 3 dimensi penting yakni kualitas makanan, lingkungan fisik, dan kualitas layanan.

1. Kualitas makanan

Kualitas makanan merupakan keseragaman setiap menu yang ditawarkan oleh suatu restoran dan dapat dicapai dengan menetapkan suatu standar produk lalu melakukan pengontrolan untuk menghasilkan kualitas makanan yang diinginkan (Sugianto dan Sugiharto, 2013). Menurut Namkung dan Jang (2007) untuk dapat mengukur kualitas makanan ada beberapa indikator yang harus digunakan yakni:

- Presentasi = tampilan suatu makanan saat disajikan kepada konsumen.

- Variasi menu = restoran memiliki variasi menu yang beragam.

- Pilihan kesehatan = kemampuan restoran dalam menyajikan pilihan makanan yang sehat dan layak untuk dikonsumsi.

- Rasa = rasa makanan yang disajikan haruslah memiliki keterkaitan dengan budaya atau letak geografis.

- Kesegaran = kesegaran mengacu pada beberapa hal yakni kerenyahan, juiciness, dan aroma dari makanan.

- Suhu makanan $=$ cara restoran dalam menyajikan makanan kepada konsumen karena suhu makanan akan mempengaruhi rasa makanan.

2. Kualitas layanan

Kualitas layanan didapatkan dari interaksi antara karyawan dan konsumen berdasarkan kemampuan dari restoran dalam menyampaikan layanannya yang dijanjikan bagi konsumen (Canny, 2014). Markovic, Kosmic dan Stifanic (2013) menyatakan ada 5 indikator untuk mengukur kualitas layanan di sebuah restoran yakni:

- Bukti fisik = layanan yang akan diterima konsumen secara fisik.

- Daya tanggap = kesediaan dan kesadaran dalam membantu konsumen.

- Keandalan = memberikan pelayanan yang akurat serta handal sesuai dengan yang dijanjikan oleh restoran kepada konsumen.

- Jaminan = kemampuan karyawan dalam menyampaikan detail produk dan kesopanan guna meyakinkan konsumen.

- Empati = kepedulian dengan atensi secara pribadi kepada konsumen.
3. Lingkungan fisik

Lingkungan fisik membantu terciptanya suatu dining experience karena terdapat faktor-faktor penting yang mendukung atribut ini antara lain fungsi restoran, ruang restoran, warna desain dan pencahayaan sebagai stimulus penting dari dining experience (Canny, 2014). Untuk mengetahui persepsi konsumen berkaitan dengan lingkungan fisik di restoran, Ryu dan Jang (2007) menggunakan DINESCAPE. DINESCAPE dapat diartikan sebagai pekerjaan tangan buatan manusia yang ada di sekeliling area tempat makan di suatu restoran. Menurut Ryu dan Jang (2007) terdapat 6 indikator DINESCAPE yaitu:

- Estetika fasilitas = berupa rancangan arsitektur, interior dan dekorasi seperti lukisan, hiasan dinding, pemilihan warna dan perabotan.

- Suasana = elemen intangible (musik, aroma dan temperatur) yang menjadi latar belakang untuk mempengaruhi indera konsumen secara non visual.

- Pencahayaan $=$ pencahayaan restoran yang nyaman.

- Tata letak = denah ruangan, ukuran dan bentuk perlengkapan perabotan, meja, mesin dan peralatan.

- Peralatan makan = menggunakan flatware (sendok, garpu, dan pisau), glassware (gelas), chinaware (piring dan mangkok), dan linen berkualitas.

- Karyawan = kondisi visual (penampilan) dari karyawan.

\section{Kepuasan Konsumen}

Kotler dan Keller (2012) menyatakan bahwa kepuasan merupakan perasaan gembira atau kecewa yang dirasakan konsumen berdasarkan perbandingan hasil dan kinerja yang diharapkan. Penyedia layanan harus memastikan kinerjanya sesuai dengan harapan konsumen (Raychaudhur \& Farooqi, 2013). Dengan begitu restoran dapat fokus untuk memenuhi kebutuhan konsumen dan mencapai perilaku menyenangkan dari konsumen yang puas (Choi \& Jeon, 2012). Menurut Murambi dan Bwisa (2014) mengukur kepuasan konsumen sama dengan mengukur perasaan manusia. Hal tersebut dapat dikatakan sulit karena dalam memenuhi kepuasannya setiap konsumen memiliki kebutuhan, tujuan, dan pengalaman yang berbeda (Pizam, Shapoval \& Ellis, 2016). Untuk mengukur kepuasan konsumen Huang, Yen, Liu dan Chang (2014) menggunakan 2 dimensi yakni:

- Perasaan konsumen = perasaan konsumen setelah melakukan transaksi. 
- Ekspektasi kinerja = adanya kesesuaian antara ekspektasi konsumen terhadap suatu produk yang akan dibeli dengan kenyataan yang didapat.

\section{Revisit Intention}

Revisit intention merupakan suatu konsep yang berasal dari behavioural intention, dimana adanya keinginan untuk datang kembali, menyarankan kepada orang lain, serta menyebarkan kesan yang positif (Bintarti dan Kurniawan, 2017). Revisit intention juga mengacu pada kondisi psikologis, dimana jika terbentuknya komitmen pada saat menggunakan suatu produk maupun layanan akan menimbulkan keinginan untuk melakukan konsumsi lagi (Huang et al., 2014). Revisit intention merupakan hal yang mudah dijaga dan dikendalikan namun juga dapat menjadi hal yang mudah hilang. Hal ini sangat tergantung pada kepuasan konsumen restoran dan tindakan pihak restoran mendorong konsumen untuk melakukan pembelian kembali (Bae, Slevitch dan Tomas, 2018). Anwar, Suharyono, dan Bafadhal (2018) mengukur revisit intention dengan dua dimensi yaitu:

- Intend to recommend $=$ niat untuk memberikan rekomendasi

- Intend to revisit = niat untuk melakukan kunjungan ulang

\section{Model Penelitian}

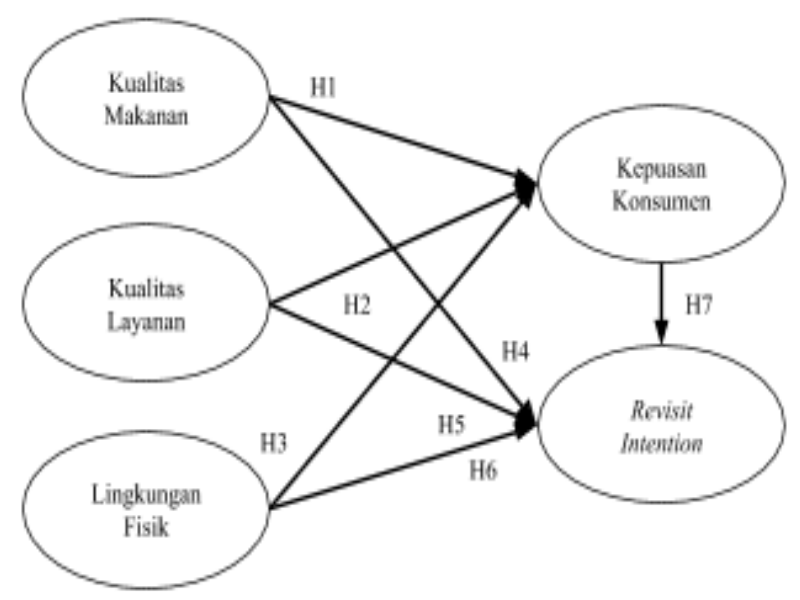

Gambar 2. Model Penelitian

\section{METODE PENELITIAN}

Penelitian ini menggunakan pendekatan kausal untuk mengetahui dan menganalisis pengaruh dining experience terhadap kepuasan konsumen dan revisit intention di restoran Korea di Surabaya pada era new normal. Populasi pada penelitian ini adalah konsumen restoran Korea di Surabaya. Peneliti menggunakan metode non-probability sampling dengan menggunakan teknik purposive sampling. Penelitian ini melibatkan 100 responden. Kriteria responden sebagai berikut: 1) usia responden adalah minimal 17 tahun, 2) responden haruslah sudah pernah berkunjung atau melakukan kunjungan kembali di salah satu restoran Korea di Surabaya yakni Magal, Son $G a$, Myoung Ga, Galbisal, Ahjumma Kitchen atau Gojumong pada era new normal (Juli 2020 - Oktober 2020).

Pengumpulan data dilakukan secara online menggunakan bantuan google form yang dikirimkan dalam bentuk link. Link tersebut dibagikan melalui media sosial seperti line, whatsapp, dan instagram kepada responden yang memenuhi kriteria. Kuesioner yang dibagikan menggunakan Five Likert Scale Method. Kuesioner terbagi menjadi tiga bagian. Bagian pertama berisi pertanyaan saringan untuk memastikan responden yang mengisi kuesioner memenuhi kriteria penelitian. Bagian kedua yang berisi pertanyaan umum mengenai profil responden. Selanjutnya bagian ketiga berisikan pertanyaan yang berkaitan dengan variabel penelitian. Teknik analisa data akan menggunakan Structural Equation Modeling (SEM) melalui pendekatan Partial Least Square (PLS).

Uji validitas menggunakan korelasi Bivariate Pearson pada software SPSS dengan signifikansi 5\% dan jumlah responden sebanyak 30 orang ( $\mathrm{r}$ tabel 0,361 ). Jika nilai $r$ hitung $>r$ tabel maka pernyataan kuesioner dapat dikatakan valid. Berdasarkan hasil uji validitas ditemukan ada 2 indikator yang tidak valid, yakni indikator X2.1.3 (kualitas layanan) dan X3.6.2 (lingkungan fisik) dikarenakan hasil $r$ hitung $<\mathrm{r}$ tabel $(0,361)$ dieliminasi indikator tersebut.

Tabel 1. Hasil Uji Reliabilitas

\begin{tabular}{|c|c|c|c|c|}
\hline No & Variabel & $\begin{array}{c}\text { Number } \\
\text { of items }\end{array}$ & $\begin{array}{c}\text { Nilai } \\
\text { Cronbach's } \\
\text { Alpha }\end{array}$ & Keterangan \\
\hline 1 & $\begin{array}{l}\text { Kualitas } \\
\text { makanan }\end{array}$ & 7 & 0,848 & Reliabel \\
\hline 2 & Kualitas layanan & 14 & 0,874 & Reliabel \\
\hline 3 & Lingkungan fisik & 13 & 0,890 & Reliabel \\
\hline 4 & $\begin{array}{l}\text { Kepuasan } \\
\text { konsumen }\end{array}$ & 5 & 0,720 & Reliabel \\
\hline 5 & Revisit intenion & 2 & 0,603 & Reliabel \\
\hline
\end{tabular}

Uji reliabilitas pada penelitian ini menggunakan nilai Cronbach's Alpha $(\alpha)$. Data yang diperoleh dikatakan reliabel jika Cronbach's Alpha > 0,6 (Ghozali, 2014). Semua variabel dinyatakan reliabel. 


\section{HASIL PENELITIAN DAN PEMBAHASAN}

\section{Profil Responden} an ini.

Berikut disajikan tabel profil responden peneliti-

Tabel 2. Profil Responden

\begin{tabular}{|c|c|c|c|}
\hline \multicolumn{2}{|c|}{ TABEL PROFIL RESPONDEN } & \multirow{2}{*}{$\begin{array}{c}\text { Jumlah } \\
43\end{array}$} & \multirow{2}{*}{$\begin{array}{r}\% \\
43 \% \\
\end{array}$} \\
\hline \multirow{2}{*}{ Jenis Kelamin } & Laki-laki & & \\
\hline & Perempuan & 57 & $57 \%$ \\
\hline Usia & $17-25$ tahun & 27 & $27 \%$ \\
\hline \multirow{4}{*}{ Usia } & 26-35 tahun & 23 & $23 \%$ \\
\hline & $36-45$ tahun & 18 & $18 \%$ \\
\hline & 46-55 tahun & 17 & $17 \%$ \\
\hline & $>55$ tahun & 15 & $15 \%$ \\
\hline \multirow{5}{*}{$\begin{array}{l}\text { Pendidikan } \\
\text { Terakhir }\end{array}$} & SMP & 0 & $0 \%$ \\
\hline & SMA/SMK/Sederajat & 22 & $22 \%$ \\
\hline & Diploma & 9 & $9 \%$ \\
\hline & Sarjana (S1) & 59 & $59 \%$ \\
\hline & Pascasarjana (S2 \& S3) & 10 & $10 \%$ \\
\hline \multirow{8}{*}{ Pekerjaan } & Pelajar / Mahasiswa & 21 & $21 \%$ \\
\hline & Wiraswasta & 31 & $31 \%$ \\
\hline & $\begin{array}{l}\text { Pegawai Negeri / } \\
\text { Karyawan Swasta }\end{array}$ & 21 & $21 \%$ \\
\hline & Ibu Rumah Tangga & 10 & $10 \%$ \\
\hline & $\begin{array}{c}\text { Professional (dokter, } \\
\text { pengacara, konsultan, dll) }\end{array}$ & 14 & $14 \%$ \\
\hline & Food blogger & 1 & $1 \%$ \\
\hline & Food stylist & 1 & $1 \%$ \\
\hline & Guru & 1 & $1 \%$ \\
\hline \multirow{6}{*}{$\begin{array}{c}\text { Restoran } \\
\text { Korea yang } \\
\text { Dikunjungi }\end{array}$} & $\begin{array}{l}\text { Magal Korean BBQ } \\
\text { Restoran }\end{array}$ & 37 & $23 \%$ \\
\hline & Son Ga Resto & 26 & $16 \%$ \\
\hline & Ahjumma Kitchen & 31 & $19 \%$ \\
\hline & Gojumong & 18 & $11 \%$ \\
\hline & Galbisal Korean BBQ & 25 & $16 \%$ \\
\hline & Myoung Ga & 22 & $14 \%$ \\
\hline \multirow{4}{*}{$\begin{array}{c}\text { Pendapatan } \\
\text { atau Uang } \\
\text { Saku dalam } \\
\text { Sebulan }\end{array}$} & $<\operatorname{Rp} 4.200 .000$ & 21 & $21 \%$ \\
\hline & $\begin{array}{c}\mathrm{Rp} 4.200 .000-\mathrm{Rp} \\
10.000 .000\end{array}$ & 30 & $30 \%$ \\
\hline & $\begin{array}{c}\text { Rp } 10.000 .000-\mathrm{Rp} \\
15.000 .000\end{array}$ & 18 & $18 \%$ \\
\hline & > Rp 15.000.000 & 31 & $31 \%$ \\
\hline \multirow{2}{*}{ Kunjungan } & 1 kali & 22 & $22 \%$ \\
\hline & 2-3 kali & 55 & $55 \%$ \\
\hline \multirow{2}{*}{ Kunjungan } & 3-4 kali & 10 & $10 \%$ \\
\hline & $>5$ kali & 13 & $13 \%$ \\
\hline \multirow{3}{*}{ Pengeluaran } & $<\mathrm{Rp} 100.000$ & 0 & $0 \%$ \\
\hline & Rp 100.000 - Rp 200.000 & 11 & $11 \%$ \\
\hline & Rp 200.000 - Rp 300.000 & 35 & $35 \%$ \\
\hline
\end{tabular}

\begin{tabular}{cccc}
\hline \multicolumn{2}{c}{ TABEL PROFIL RESPONDEN } & Jumlah & \% \\
\hline \multirow{2}{*}{ Pengeluaran } & Rp 300.000 - Rp 400.000 & 29 & $29 \%$ \\
& $>$ Rp 400.000 & 25 & $25 \%$ \\
\hline \multirow{2}{*}{ Dengan Siapa } & Sendiri & 7 & $5 \%$ \\
Berkunjung & Teman & 48 & $32 \%$ \\
& Pacar & 16 & $11 \%$ \\
\hline \multirow{2}{*}{ Dengan Siapa } & Keluarga & 64 & $43 \%$ \\
Berkunjung & Rekan Kerja & 12 & $8 \%$ \\
& Suami & 1 & $1 \%$ \\
\hline \multirow{2}{*}{ APD } & Ya & 97 & $97 \%$ \\
& Tidak & 3 & $3 \%$ \\
\hline
\end{tabular}

Sebanyak 100 responden yang berhasil diperoleh pada penelitian ini, mayoritas adalah perempuan sebanyak 57 orang. Responden mayoritas berusia 1725 tahun. Pendidikan terakhir responden mayoritas adalah sarjana dan bekerja sebagai wiraswasta dengan pendapatan atau uang saku sebesar > Rp 15.000.000. Restoran Korea yang paling sering dikunjungi oleh responden adalah Magal Korean BBQ Restaurant dan mayoritas responden mengunjungi restoran Korea di Surabaya sebanyak 2-3 kali bersama dengan keluarga dengan rata-rata pengeluaran sekali makan sebesar Rp 200.000-300.000. Hampir seluruh responden datang dengan menggunakan alat pelindung diri (APD).

\section{Analisa Statistik Deskriptif}

Berikut analisa deskriptif dari data kuesioner yang disebarkan pada penelitian ini.

Tabel 3. Mean Kualitas Makanan

\begin{tabular}{cccc}
\hline \multicolumn{4}{c}{ Analisa Statistik Deskriptif } \\
\hline Indikator & Mean & Standar Deviasi & Keterangan \\
\hline X1.1.1 & 4.34 & 0.685 & Sangat Setuju \\
X1.1.2 & 4.42 & 0.606 & Sangat Setuju \\
X1.2.1 & 4.39 & 0.680 & Sangat Setuju \\
X1.3.1 & 4.33 & 0.604 & Sangat Setuju \\
X1.4.1 & 4.42 & 0.606 & Sangat Setuju \\
X1.4.2 & 4.43 & 0.624 & Sangat Setuju \\
X1.5.1 & 4.52 & 0.627 & Sangat Setuju \\
\hline Total & 4.41 & & Sangat Setuju \\
\hline X2.1.1 & 4.61 & 0.510 & Sangat Setuju \\
X2.1.2 & 4.68 & 0.649 & Sangat Setuju \\
X2.2.1 & 4.54 & 0.593 & Sangat Setuju \\
X2.2.2 & 3.96 & 0.764 & Setuju \\
X2.2.3 & 4.19 & 0.706 & Setuju \\
X2.3.1 & 3.97 & 0.771 & Setuju \\
X2.3.2 & 4.24 & 0.698 & Sangat Setuju \\
X2.3.3 & 4.01 & 0.718 & Setuju \\
X2.4.1 & 4.31 & 0.677 & Sangat Setuju \\
\hline
\end{tabular}




\begin{tabular}{cccc}
\hline \multicolumn{4}{c}{ Analisa Statistik Deskriptif } \\
\hline Indikator & Mean & Standar Deviasi & Keterangan \\
\hline X2.4.2 & 4.46 & 0.610 & Sangat Setuju \\
X2.4.3 & 4.43 & 0.624 & Sangat Setuju \\
X2.5.1 & 4.04 & 0.710 & Setuju \\
X2.5.2 & 3.64 & 0.894 & Setuju \\
\hline Total & $\mathbf{4 . 2 4}$ & & Sangat Setuju \\
\hline X3.1.1 & 4.48 & 0.689 & Sangat Setuju \\
X3.1.2 & 4.11 & 0.815 & Setuju \\
X3.2.1 & 4.29 & 0.832 & Sangat Setuju \\
X3.2.2 & 4.25 & 0.642 & Sangat Setuju \\
X3.3.1 & 4.29 & 0.656 & Sangat Setuju \\
X3.3.2 & 4.22 & 0.629 & Setuju \\
X3.4.1 & 4.40 & 0.651 & Sangat Setuju \\
X3.4.2 & 4.41 & 0.726 & Sangat Setuju \\
X3.5.1 & 4.35 & 0.609 & Sangat Setuju \\
X3.5.2 & 4.05 & 0.845 & Setuju \\
X3.6.1 & 4.27 & 0.584 & Sangat Setuju \\
X3.6.3 & 4.35 & 0.657 & Sangat Setuju \\
\hline Total & $\mathbf{4 . 2 9}$ & & Sangat Setuju \\
\hline Y1 & 4.38 & 0.582 & Sangat Setuju \\
Y2 & 4.29 & 0.591 & Sangat Setuju \\
Y3 & 4.22 & 0.690 & Setuju \\
Y4 & 4.36 & 0.644 & Sangat Setuju \\
Y5 & 4.28 & 0.668 & Sangat Setuju \\
\hline Total & $\mathbf{4 . 3 1}$ & & Sangat Setuju \\
\hline Z1 & 4.39 & 0.618 & Sangat Setuju \\
Z2 & 4.50 & 0.628 & Sangat Setuju \\
\hline Total & $\mathbf{4 . 4 5}$ & & Sangat Setuju \\
\hline & & &
\end{tabular}

Berdasarkan tabel di atas terlihat bahwa responden sangat setuju dengan semua indikator dari variabel kualitas makanan. Hal ini terlihat pada nilai total ratarata variabel kualitas makanan yaitu, 4.41 yang berarti kualitas makanan di restoran Korea sudah sangat baik. Untuk kualitas layanan responden juga sangat setuju bahwa layanan yang disampaikan oleh restoran Korea di Surabaya selama era new normal tergolong sangat baik dengan total nilai total rata-rata sebesar 4.24. Secara keseluruhan lingkungan fisik mendapatkan total rata-rata 4.29 yang artinya responden sangat setuju bahwa lingkungan fisik restoran Korea di Surabaya selama era new normal sangat baik dan indikator- indikator yang digunakan sudah bisa menggambarkan lingkungan fisik restoran Korea di Surabaya. Kepuasan konsumen diketahui bahwa responden sangat setuju dengan kepuasan konsumen yang dirasakan selama makan di restoran Korea di Surabaya dengan nilai rata-rata sebesar 4.31. Untuk hasil mean revisit intention diketahui bahwa responden sangat setuju untuk melakukan kunjungan ulang ke restoran Korea di Surabaya pada era new normal dengan nilai rata-rata sebesar 4.45 .

\section{Evaluasi Outer Model}

1. Validitas Konvergen

Indikator memenuhi validitas konvergen apabila nilai loading factor $>0.5$. Gambar berikut dapat dilihat bahwa semua indikator valid karena nilai yang dihasilkan $>0.5$

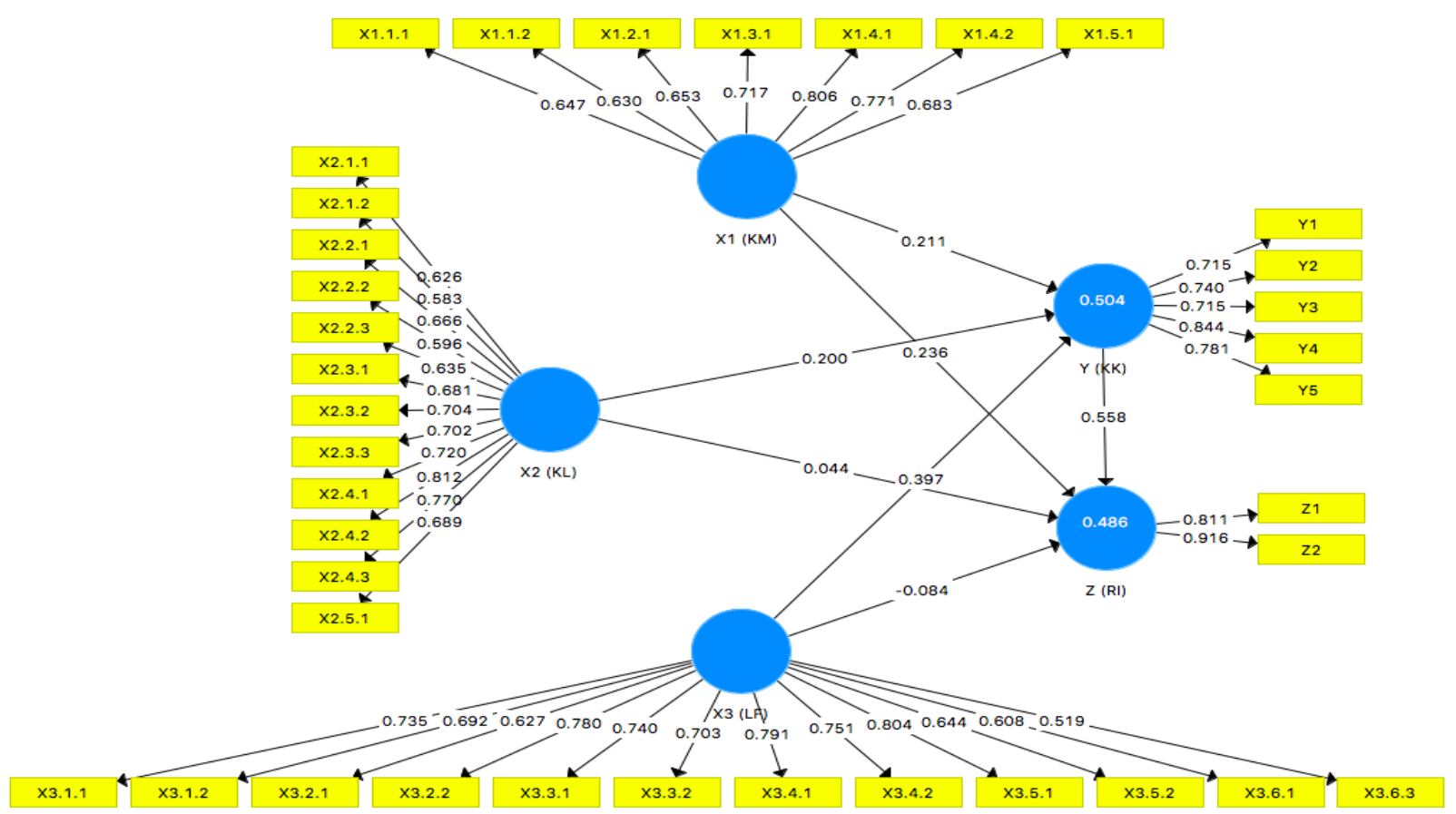

Gambar 3. Hasil Uii Validitas Konvergen 
2. Validitas Diskriminan

Model penelitian dapat dikatakan memiliki validitas diskriminan yang baik apabila nilai korelasi antara indikator dengan variabelnya lebih besar daripada nilai korelasi indikator dengan variabel yang lainnya. Berikut merupakan hasil nilai cross loading pada penelitian ini

Tabel 4. Hasil Uji Validitas Diskriminan

\begin{tabular}{|c|c|c|c|c|c|}
\hline \multirow{2}{*}{ Indikator } & \multicolumn{5}{|c|}{ Nilai Cross Loading } \\
\hline & X1 & $\mathbf{X} 2$ & $\mathbf{X 3}$ & $\mathbf{Y}$ & $\mathbf{Z}$ \\
\hline X1.1.1 & 0.647 & 0.412 & 0.427 & 0.237 & 0.255 \\
\hline $\mathrm{X} 1.1 .2$ & 0.630 & 0.379 & 0.432 & 0.372 & 0.442 \\
\hline $\mathrm{X} 1.2 .1$ & 0.653 & 0.300 & 0.368 & 0.460 & 0.466 \\
\hline $\mathrm{X} 1.3 .1$ & 0.717 & 0.426 & 0.443 & 0.406 & 0.314 \\
\hline $\mathrm{X} 1.4 .1$ & 0.806 & 0.542 & 0.494 & 0.449 & 0.377 \\
\hline $\mathrm{X} 1.4 .2$ & 0.771 & 0.638 & 0.510 & 0.454 & 0.391 \\
\hline $\mathrm{X} 1.5 .1$ & 0.683 & 0.534 & 0.541 & 0.503 & 0.378 \\
\hline $\mathrm{X} 2.1 .1$ & 0.488 & 0.626 & 0.434 & 0.483 & 0.375 \\
\hline $\mathrm{X} 2.1 .2$ & 0.537 & 0.583 & 0.394 & 0.381 & 0.340 \\
\hline $\mathrm{X} 2.2 .1$ & 0.528 & 0.666 & 0.340 & 0.281 & 0.329 \\
\hline $\mathrm{X} 2.2 .2$ & 0.375 & 0.596 & 0.215 & 0.232 & 0.221 \\
\hline $\mathrm{X} 2.2 .3$ & 0.383 & 0.635 & 0.256 & 0.284 & 0.269 \\
\hline $\mathrm{X} 2.3 .1$ & 0.301 & 0.681 & 0.350 & 0.256 & 0.336 \\
\hline $\mathrm{X} 2.3 .2$ & 0.321 & 0.704 & 0.367 & 0.448 & 0.304 \\
\hline $\mathrm{X} 2.3 .3$ & 0.421 & 0.702 & 0.372 & 0.338 & 0.317 \\
\hline $\mathrm{X} 2.4 .1$ & 0.461 & 0.720 & 0.592 & 0.458 & 0.294 \\
\hline $\mathrm{X} 2.4 .2$ & 0.563 & 0.812 & 0.560 & 0.580 & 0.352 \\
\hline X2.4.3 & 0.562 & 0.770 & 0.513 & 0.490 & 0.407 \\
\hline X2.5.1 & 0.400 & 0.689 & 0.376 & 0.300 & 0.275 \\
\hline X3.1.1 & 0.469 & 0.322 & 0.735 & 0.548 & 0.347 \\
\hline X3.1.2 & 0.377 & 0.321 & 0.692 & 0.418 & 0.241 \\
\hline X3.2.1 & 0.394 & 0.248 & 0.627 & 0.310 & 0.200 \\
\hline X3.2.2 & 0.561 & 0.468 & 0.780 & 0.448 & 0.311 \\
\hline X3.3.1 & 0.453 & 0.438 & 0.740 & 0.456 & 0.274 \\
\hline X3.3.2 & 0.507 & 0.370 & 0.703 & 0.412 & 0.352 \\
\hline X3.4.1 & 0.452 & 0.515 & 0.791 & 0.543 & 0.385 \\
\hline X3.4.2 & 0.515 & 0.463 & 0.751 & 0.595 & 0.426 \\
\hline X3.5.1 & 0.560 & 0.546 & 0.804 & 0.489 & 0.395 \\
\hline X3.5.2 & 0.357 & 0.418 & 0.644 & 0.469 & 0.361 \\
\hline X3.6.1 & 0.494 & 0.483 & 0.608 & 0.351 & 0.319 \\
\hline X3.6.3 & 0.375 & 0.466 & 0.519 & 0.384 & 0.197 \\
\hline $\mathrm{Y} 1$ & 0.472 & 0.359 & 0.478 & 0.715 & 0.460 \\
\hline Y2 & 0.421 & 0.351 & 0.485 & 0.740 & 0.463 \\
\hline Y3 & 0.447 & 0.432 & 0.445 & 0.715 & 0.476 \\
\hline Y4 & 0.486 & 0.575 & 0.553 & 0.844 & 0.586 \\
\hline Y5 & 0.469 & 0.457 & 0.528 & 0.781 & 0.553 \\
\hline $\mathrm{Z} 1$ & 0.314 & 0.277 & 0.323 & 0.492 & 0.811 \\
\hline $\mathrm{Z} 2$ & 0.590 & 0.505 & 0.461 & 0.651 & 0.916 \\
\hline
\end{tabular}

Berdasarkan nilai cross loading pada tabel tersebut, nilai korelasi setiap indikator memiliki nilai cross loading lebih besar pada variabelnya sendiri dibandingkan dengan variabel lainnya. Dengan demikian seluruh indikator memiliki validitas diskriminan yang baik

3. Composite Reliability dan Cronbach's Alpha Berdasarkan hasil uji reliabilitas nilai composite reliability seluruh variabel sudah lebih besar dari 0,7 dan nilai cronbach's alpha juga lebih besar dari 0,6. Dengan demikian dapat dinyatakan bahwa masingmasing variabel pada penelitian ini sudah reliabel.

Tabel 5. Nilai Composite Reliability dan Cronbach's Alpha

\begin{tabular}{lcc}
\hline \multicolumn{1}{c}{ Variabel } & $\begin{array}{c}\text { Composite } \\
\text { Reliability }\end{array}$ & $\begin{array}{c}\text { Cronbach's } \\
\text { Alpha }\end{array}$ \\
\hline Kualitas makanan (X1) & 0.872 & 0.830 \\
Kualitas layanan (X2) & 0.913 & 0.897 \\
Lingkungan fisik (X3) & 0.921 & 0.906 \\
Kepuasan konsumen (Y) & 0.872 & 0.817 \\
Revisit intenion (Z) & 0.856 & 0.674 \\
\hline
\end{tabular}

\section{Evaluasi Inner Model}

1. Uji R-Square

Berdasarkan tabel berikut, nilai $R$-Square variabel kepuasan konsumen sebesar 0.504 menyatakan bahwa kualitas makanan, kualitas layanan dan lingkungan fisik mempengaruhi kepuasan konsumen restoran Korea di Surabaya sebesar $50.4 \%$, sedangkan sisanya $49.6 \%$ dijelaskan oleh variabel lain yang tidak diteliti. $R$-Square dari revisit intention sebesar 0.486 yang artinya kualitas makanan, kualitas layanan, lingkungan fisik dan kepuasan konsumen mempengaruhi revisit intention konsumen restoran Korea di Surabaya sebesar $48.6 \%$, selebihnya dipengaruhi variabel selain yang diukur pada penelitian ini.

Tabel 6. R-Square

\begin{tabular}{lc}
\hline \multicolumn{1}{c}{ Variabel } & R-Square \\
\hline Kepuasan Konsumen $(\mathrm{Y})$ & 0.504 \\
Revisit Intention $(\mathrm{Z})$ & 0.486 \\
\hline
\end{tabular}

2. Q-Square

Perhitungan $Q$-Square dapat dilakukan dengan rumus berikut :

$\mathrm{Q}^{2}=1-\left(1-\mathrm{R}^{2} 1\right)\left(1-\mathrm{R}^{2} 2\right)$

$\mathrm{Q}^{2}=1-(1-0.504)(1-0.486)$

$\mathrm{Q}^{2}=0.745056=74.5 \%$ 


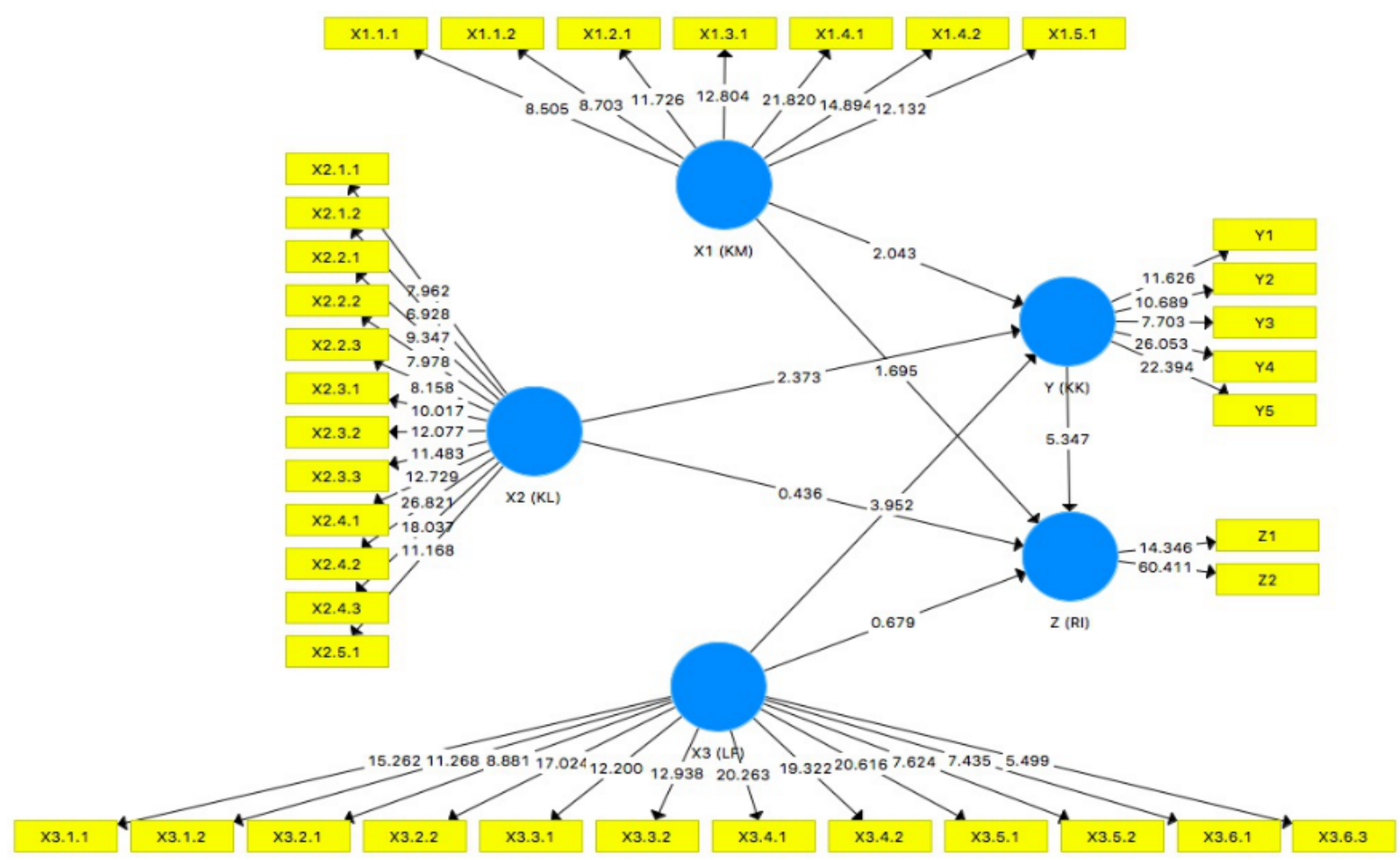

Gambar 4. Hasil Bootstrapping

Nilai Q-Square sebesar 0.745056 atau sudah $>0$ yang dapat dinyatakan bahwa model penelitian mengandung predictive relevance.

3. Uji Hipotesis

Penelitian ini menggunakan hipotesis dua ekor (two-tailed) maka nilai $t$-statistics harus di atas 1,96 yang artinya variabel mempunyai pengaruh yang kuat. Nilai $t$-statistics didapatkan melalui prosedur bootstrapping terlihat pada tabel 7 .

Tabel 7. Nilai $t$-statistics

\begin{tabular}{|c|c|c|c|c|}
\hline $\begin{array}{l}\text { Hipo- } \\
\text { tesis }\end{array}$ & $\begin{array}{l}\text { Pengaruh } \\
\text { Langsung }\end{array}$ & $\begin{array}{l}\text { Original } \\
\text { Sample } \\
\text { (O) }\end{array}$ & $\begin{array}{c}\text { t Statistics } \\
\text { (|O/STDE } \\
\text { V|) }\end{array}$ & P Values \\
\hline $\mathrm{H} 1$ & $\begin{array}{l}\text { X1 (Kualitas } \\
\text { Makanan) } \rightarrow \text { Y } \\
\text { (Kepuasan } \\
\text { Konsumen) }\end{array}$ & 0.211 & 2.043 & 0.042 \\
\hline $\mathrm{H} 2$ & $\begin{array}{l}\text { X2 (Kualitas } \\
\text { Layanan) } \rightarrow \text { Y } \\
\text { (Kepuasan } \\
\text { Konsumen) }\end{array}$ & 0.200 & 2.373 & 0.018 \\
\hline $\mathrm{H} 3$ & $\begin{array}{l}\text { X3 (Lingkungan } \\
\text { Fisik) } \rightarrow \text { Y } \\
\text { (Kepuasan } \\
\text { Konsumen) }\end{array}$ & 0.397 & 3.952 & 0.000 \\
\hline $\mathrm{H} 4$ & $\begin{array}{l}\text { X1 (Kualitas } \\
\text { Makanan) } \rightarrow \mathrm{Z} \\
\text { (Revisit } \\
\text { Intention) }\end{array}$ & 0.236 & 1.695 & 0.091 \\
\hline
\end{tabular}

\begin{tabular}{|c|c|c|c|c|}
\hline $\begin{array}{l}\text { Hipo- } \\
\text { tesis }\end{array}$ & $\begin{array}{l}\text { Pengaruh } \\
\text { Langsung }\end{array}$ & $\begin{array}{l}\text { Original } \\
\text { Sample } \\
\text { (O) }\end{array}$ & $\begin{array}{c}\text { t Statistics } \\
\text { (|O/STDE } \\
\text { V|) }\end{array}$ & P Values \\
\hline H5 & $\begin{array}{l}\text { X2 (Kualitas } \\
\text { Layanan) } \rightarrow \mathrm{Z} \\
\text { (Revisit } \\
\text { Intention) }\end{array}$ & 0.044 & 0.436 & 0.663 \\
\hline H6 & $\begin{array}{l}\text { X3 (Lingkungan } \\
\text { Fisik) } \rightarrow \mathrm{Z} \\
\text { (Revisit } \\
\text { Intention) }\end{array}$ & -0.084 & 0.679 & 0.497 \\
\hline $\mathrm{H} 7$ & $\begin{array}{l}\mathrm{Y}(\text { Kepuasan } \\
\text { Konsumen }) \rightarrow \mathrm{Z} \\
(\text { Revisit } \\
\text { Intention) }\end{array}$ & 0.558 & 5.347 & 0.000 \\
\hline
\end{tabular}

Berdasarkan tabel 7 kualitas makanan, kualitas layanan dan lingkungan fisik berpengaruh signifikan terhadap kepuasan konsumen namun tidak signifikan terhadap revisit intention. Selain itu kepuasan konsumen juga berpengaruh signifikan terhadap revisit intention. Berdasarkan hasil ini maka hipotesis $\mathrm{H} 1, \mathrm{H} 2, \mathrm{H} 3$, dan $\mathrm{H} 7$ diterima sedangkan hipotesis $\mathrm{H} 4, \mathrm{H} 5$, dan $\mathrm{H} 6$ ditolak.

\section{Pembahasan}

Penelitian ini menyatakan bahwa kualitas makanan berpengaruh signifikan terhadap kepuasan konsumen restoran Korea di Surabaya pada era new normal. Hasil ini semakin menegaskan temuan 
penelitian terdahulu oleh Ryu dan Han (2010), Yong et al. (2013) dan Namkung dan Jang (2007) bahwa kualitas makanan berdampak signifikan terhadap kepuasan konsumen. Berdasarkan loading factor indikator kualitas makanan yang mendapatkan nilai tertinggi yakni "Restoran Korea di Surabaya menyajikan makanan yang segar". Hasil tersebut menunjukkan bahwa restoran Korea menggunakan bahanbahan yang segar dalam mengolah makanan yang disajikan kepada konsumen, menyajikan makanan yang segar tidak hanya akan menjaga tekstur dan rasa makanan tetapi juga mempertahankan nutrisi dari makanan tersebut. Berdasarkan hasil analisa statistik deskriptif, nilai mean tertinggi kualitas makanan terdapat pada indikator "Restoran Korea di Surabaya menyajikan makanan dengan suhu yang tepat sesuai dengan jenis makanannya ( $\sup =$ panas, salad $=$ dingin)". Hal ini menunjukkan restoran Korea di Surabaya menyajikan makanan dengan tepat waktu yang membuat suhu makanan masih tetap terjaga. Makanan yang disajikan dengan suhu yang sesuai membuat konsumen merasa puas karena suhu makanan yang sesuai membuat makanan nikmat dikonsumsi. Hal ini mendukung konsumen merasa puas atas pengalaman makan di restoran Korea yang telah dipilih.

Kualitas layanan menunjukkan hasil yang berpengaruh signifikan terhadap kepuasan konsumen. Temuan pada penelitian ini sejalan dengan temuan penelitian terdahulu oleh Qin dan Prybutok (2009), Canny (2014), Hutama (2014) dan Mannan et al. (2019) bahwa kualitas layanan berdampak signifikan terhadap kepuasan konsumen. Berdasarkan loading factor dari indikator "Karyawan restoran Korea di Surabaya sopan saat melayani konsumen" mendapatkan nilai tertinggi. Melayani konsumen dengan sopan membuat konsumen merasa sangat dihargai dan dari perasaan dihargai tersebut yang menimbulkan kepuasan terhadap pelayanan yang diberikan restoran Korea di Surabaya. Berdasarkan hasil analisa statistik deskriptif, nilai mean tertinggi kualitas layanan terdapat pada indikator "Restoran Korea di Surabaya melakukan pengecekan suhu tubuh konsumen sebelum memasuki area restoran". Hal ini menunjukkan bahwa Restoran Korea di Surabaya taat dalam menjalankan protokol kesehatan pada era new normal dengan selalu melakukan pengecekan suhu tubuh konsumen sehingga konsumen merasa aman saat makan yang juga menimbulkan rasa puas akan pelayanan yang diberikan.

Lingkungan fisik juga berdampak signifikan terhadap kepuasan konsumen restoran Korea di Surabaya pada era new normal. Hasil ini semakin menegaskan hasil penelitian terdahulu dari Jin et al. (2012), Ryu et al. (2012), Erkmen dan Hencer (2019), dan Mannan et al. (2019). Berdasarkan hasil loading factor indikator "Suhu ruangan restoran Korea di Surabaya membuat saya merasa nyaman" mendapatkan nilai tertinggi. Dapat dilihat bahwa suhu ruangan juga menjadi faktor pertimbangan yang membuat konsumen merasa puas. Kenyamanan suhu ruangan menentukan pula pengalaman makan yang menyenangkan karena selama konsumen menikmati makanan di restoran yang terlalu dingin atau kurang dingin, membuat konsumen gelisah. Jika suhu di restoran nyaman akan membuat konsumen merasa puas ketika bersantap di restoran Korea di Surabaya. Berdasarkan hasil analisa statistik deskriptif, nilai mean tertinggi pada indikator "Restoran Korea di Surabaya memiliki desain interior yang menggambarkan budaya Korea". Dapat dilihat bahwa restoran Korea di Surabaya mampu menggambarkan budaya Korea dengan baik dan mirip pada desain interiornya yang menyebabkan konsumen merasa puas. Desain interior yang mampu menggambarkan budaya Korea tersebut mampu menarik konsumen terutama konsumen wanita dan para pecinta budaya Korea karena selain menikmati makanan Korea tetapi juga sekaligus merasakan suasana seperti di Korea.

Temuan berikutnya menyatakan bahwa kualitas makanan tidak berdampak signifikan terhadap revisit intention konsumen restoran Korea di Surabaya pada era new normal. Temuan penelitian ini berseberangan dengan temuan penelitian terdahulu oleh Perutkova (2009), Yan et al. (2013), dan Richardson (2019). Hal ini dikarenakan meskipun restoran Korea di Surabaya sudah menyajikan menu yang beragam dan lezat namun masih ada banyak pilihan restoran etnik lainnya di Surabaya seperti restoran Jepang, Meksiko, Italia dan lain sebagainya yang menyajikan makanan dengan kualitas yang sama baiknya atau lebih baik. Saat ini di Surabaya banyak pilihan restoran etnik yang menjadi pilihan mendapatkan dining experience selain di restoran Korea. Kondisi seperti ini mendukung konsumen tidak hanya datang ke satu restoran Korea saja namun juga mencoba restoran Korea lainnya dan akan membandingkan restoran mana yang memberikan kualitas makanan terbaik.

Temuan berikutnya yaitu kualitas layanan tidak berpengaruh signifikan terhadap revisit intention konsumen restoran Korea di Surabaya pada era new normal. Temuan penelitian ini tidak sependapat dengan temuan penelitian yang dilakukan oleh Yong et al. (2013) yang menyatakan kualitas layanan berpengaruh signifikan terhadap revisit intention. Temuan ini sependapat dengan penelitian terdahulu 
oleh Namin (2017) terhadap sebuah restoran cepat saji paling besar dan populer di Amerika Serikat yang menyatakan bahwa meskipun konsumen telah dilayani dengan baik oleh pihak restoran belum tentu hal tersebut secara langsung akan mendorong konsumen untuk melakukan kunjungan kembali di masa mendatang. Hal ini bisa terjadi karena konsumen memiliki kecenderungan untuk mencoba restoranrestoran serupa lainnya.

Variabel lingkungan fisik ditemukan tidak berpengaruh signifikan terhadap revisit intention konsumen restoran Korea di Surabaya pada era new normal. Hasil penelitian ini berbeda dengan hasil penelitian yang dilakukan oleh Ryu dan Jang (2007) dan Marinkovic et al. (2014) dimana lingkungan fisik berpengaruh terhadap revisit intention sedangkan pada penelitian ini lingkungan fisik tidak berdampak terhadap revisit intention konsumen pada era new normal. Hal ini dapat terjadi karena mayoritas restoran Korea di Surabaya memiliki dekorasi dan suasana yang hampir sama. Kondisi ini membuat konsumen cenderung merasakan suasana yang monoton sehingga tidak ingin melakukan kunjungan kembali ke restoran Korea di Surabaya dan lebih memilih untuk pergi ke restoran lainnya. Terutama saat era new normal ini, konsumen sangat memperhatikan kebersihan lingkungan restoran mulai dari tata letak, kebersihan alat makan, kebersihan fasilitas restoran hingga penampilan karyawan (menggunakan face shield, masker, dan sarung tangan). Hal tersebut yang menjadi pertimbangan konsumen karena merasa kurang leluasa ketika bersantap mengingat harus mematuhi protokol kesehatan sehingga konsumen akan mengevaluasi kondisi ini untuk mau berkunjung kembali.

Temuan yang terakhir menunjukkan bahwa kepuasan konsumen berpengaruh signifikan terhadap revisit intention konsumen restoran Korea di Surabaya pada era new normal. Temuan penelitian ini sependapat dengan penelitian terdahulu yang digagas oleh Yong et al. (2013) dan Mannan et al. (2019). Kepuasan konsumen mempengaruhi keputusan konsumen untuk melakukan kunjungan kembali ke restoran Korea di Surabaya pada era new normal. Merujuk hasil loading factor indikator "Konsumen puas dengan layanan yang diberikan oleh restoran Korea di Surabaya sesuai dengan keinginan konsumen" mendapatkan nilai tertinggi. Bukti ini menandakan bahwa konsumen puas dengan layanan dari restoran Korea di Surabaya cenderung memiliki niat untuk mengunjungi kembali. Hasil ini didukung oleh nilai nilai mean tertinggi terdapat pada indikator "Konsumen mempunyai pengalaman yang menyenangkan selama makan di restoran Korea di Surabaya" dan "Konsumen puas dengan layanan yang diberikan oleh restoran Korea di Surabaya sesuai dengan keinginan konsumen". Dapat dilihat bahwa restoran Korea di Surabaya dapat memberikan pelayanan yang baik dan memenuhi ekspektasi konsumen sehingga mayoritas konsumen mempunyai pengalaman yang menyenangkan dan puas atas layanan yang disampaikan oleh restoran Korea di Surabaya.

\section{SIMPULAN DAN SARAN}

\section{Kesimpulan}

1. Kualitas makanan berpengaruh signifikan terhadap kepuasan konsumen restoran Korea di Surabaya pada era new normal.

2. Kualitas layanan berpengaruh signifikan terhadap kepuasan konsumen restoran Korea di Surabaya pada era new normal.

3. Lingkungan fisik berpengaruh signifikan terhadap kepuasan konsumen restoran Korea di Surabaya pada era new normal.

4. Kualitas makanan tidak berpengaruh signifikan terhadap revisit intention konsumen restoran Korea di Surabaya pada era new normal.

5. Kualitas layanan tidak berpengaruh signifikan terhadap revisit intention konsumen restoran Korea di Surabaya pada era new normal.

6. Lingkungan fisik tidak berpengaruh signifikan terhadap revisit intention konsumen restoran Korea di Surabaya pada era new normal.

7. Kepuasan konsumen berpengaruh signifikan terhadap revisit intention konsumen restoran Korea di Surabaya pada era new normal.

\section{Saran}

Merujuk temuan penelitian ini, maka penulis menyampaikan beberapa saran sebagai berikut:

1. Untuk kualitas makanan restoran Korea di Surabaya, dari hasil nilai mean seluruh indikator berada di kategori sangat setuju. Hal tersebut membuktikan bahwa kualitas makanan restoran Korea di Surabaya sudah sangat baik. Sangat diharapkan pihak restoran Korea di Surabaya dapat mempertahankan hasil yang baik ini dan tetap berinovasi untuk semakin meningkatkan kualitas makanan yang dimiliki.

2. Untuk kualitas layanan, pemilik restoran Korea di Surabaya yang sudah baik diharapkan untuk dapat dipertahankan. Agar dapat memberikan perhatian yang lebih, dengan cara melakukan pembagian karyawan ke beberapa area atau meja yang harus dilayani sehingga pelayanan lebih efisien dan konsumen lebih mendapat perhatian. 
3. Untuk lingkungan fisik, pemilik restoran Korea di Surabaya diharapkan dapat memilih lukisan atau gambar yang lebih menarik dan cocok dengan budaya Korea sehingga konsumen dapat merasakan suasana restoran Korea yang otentik. Berikutnya pemilik restoran diharapkan untuk memperhatikan kebersihan alat-alat makan agar tidak terkontaminasi bakteri atau virus dengan membungkus peralatan makan menggunakan tisu atau plastik.

4. Pada era new normal diharapkan restoran Korea di Surabaya untuk menjaga konsisten dan disiplin dalam menerapkan protokol kesehatan di dalam restoran. Karyawan restoran diharapkan selalu menggunakan APD (masker, face shield, dan sarung tangan) pada saat menyampaikan layanan kepada konsumen untuk mencegah penyebaran virus dan agar terciptanya rasa aman bagi konsumen ketika makan di restoran.

5. Variabel kualitas makanan, kualitas layanan, lingkungan fisik, dan kepuasan pelanggan hanya berpengaruh sebesar $48,6 \%$ terhadap revisit intention, sehingga untuk penelitian berikutnya penulis menyarankan agar dapat meneliti pengaruh variabel lain seperti perceived value / price, promosi, $e$ WOM, brand image, brand trust, loyalitas konsumen dan lain sebagainya terhadap revisit intention di restoran Korea di Surabaya.

\section{DAFTAR REFERENSI}

Anwar, L. A., Suharyono, S., \& Bafadhal, A. S. (2018). Pengaruh dining service quality (dineserv) terhadap customer satisfaction dan revisit intention (survei pada pelanggan D'COST Seafood Restaurant Malang Town Square). Jurnal Administrasi Bisnis, 58(1), 27-35.

Bae, S., Slevitch, L., \& Tomas, S. (2018). The Effects of Restaurant Attributes on Satisfaction and Return Patronage Intentions: Evidence from Solo Diners' Experiences in the United States. Cogent Business \& Management, 1-16.

Bahurekso, P. R. (2015). Mengenal makanan Korea lewat ajang k-food fair 2015. Retrieved from https://www.medcom.id/rona/wisatakuliner/lKY4Aaxk-mengenal-makanan-korealewat-ajang-k-food-fair-2015.

Bintarti, S., \& Kurniawan, E. N. (2017). A study of revisit intention: Experiential quality and image of Muara Beting tourism site in Bekasi District. European Research Studies Journal, 20(2A), 521-537.
Canny, I. U. (2014). Measuring the mediating role of dining experience attributes on customer satisfaction and its impact on behavioral intentions of casual dining restaurant in Jakarta. International Journal of Innovation, Management and Technology, 5(1), 25-29.

Choi, B. \& Jeon, H. (2012). The relationship between employee satisfaction and customer satisfaction. Journal of Services Marketing, 26(5), 332 - 341.

Ghozali, I. (2014). Structural equation modeling: Metode alternatif dengan Partial Least Square $(P L S)$. (Edisi ke-4). Semarang: Badan Penerbit Universitas Diponegoro.

Ha, J., \& Jang, S. S. (2010). Perceived values, satisfaction, and behavioral intentions: The role of familiarity in Korean restaurants. International Journal of Hospitality Management, 29(1), 2-13.

Haryani, I. (2012). Korean wanna be. Yogyakarta: EAZY Book.

Hasanah, U. (2020). Daya Tarik menjamurnya restoran Korea di Yogyakarta. Sosiologi Reflektif, 14(2), $255-270$.

Huang, C. C., Yen, S. W., Liu, C. Y., \& Chang, T. P. (2014). The relationship among brand equity, customer satisfaction, and brand resonance to repurchase intention of cultural and creative industries in Taiwan. International Journal of Organizational Innovation, 6(3), 106-120.

Kotler, P. T. \& Keller, K. L. (2012). According to Kotler \& Keller: Manajemen pemasaran. Jilid II Edisi Ketiga Belas.B. Sabran (Trans.). Jakarta: Erlangga.

Kotschevar, L.H. \& Withrow, D. (2008). Management by menu. 4th Edition. United States of America: John Wiley \& Sons.

Marinkovic, V., Senic, V., Ivkov, D., Dimitrovski, D., \& Bjelic, M. (2014).

The antecedents of satisfaction and revisit intentions for full-service restaurants. Marketing Intelligence \& Planning, 32(3), 311-327.

Markovic, S., Komsic, J., \& Stifanic, M. (2013). Measuring service quality in city restaurant settings using DINESERV scale. Recent Advances in Business Management and Marketing, 176181.

Murambi, D.N. \& Bwisa, H.M. (2014). Service quality and customer satisfaction in public transport sector in Kenya: A survey of shuttle travelers in Kitale Terminus. International Journal of Academic Research in Business and Social Sciences, 4(19), 1167. 
Namkung, Y., \& Jang, S. (2007). Does food quality really matter in restaurants? Its impact on customer satisfaction and behavioral intentions. Journal of Hospitality \& Tourism Research, 31(3), 387-409.

Pemerintah Kota Surabaya. (2020). Peraturan Walikota Surabaya Nomor 28 Tahun 2020 tentang tatanan normal baru pada kondisi pandemi Corona Virus Disease 2019 (COVID-19) di kota Surabaya. Surabaya, Indonesia: Penulis.

Pizam, A., Shapoval, V., \& Ellis, T. (2016). Customer satisfaction and its measurement in hospitality enterprises: A revisit and update. International Journal of Contemporary Hospitality Management, 28(1), 2-35.

Raychaudhuri \& Farooqi, R. (2013). A study on the effects of dimensions of service quality on customer satisfaction in the indian HT hardware industry with special emphasis on medium size B2B sector. Global Business Review, 14(3), 507527.
Ryu, K., \& Jang, S. S. (2007). The effect of environmental perceptions on behavioral intentions through emotions: The case of upscale restaurants. Journal of Hospitality \& Tourism Research, 31(1), 56-72.

Ryu, K., Lee, H. R., \& Kim, W. G. (2012). The influence of the quality of the physical environment, food, and service on restaurant image, customer perceived value, customer satisfaction, and behavioral intentions. International Journal of Contemporary Hospitality Management, 24(2), 200-223.

Sugianto, J., \& Sugiharto, S. (2013). Analisa pengaruh service quality, food quality, dan price terhadap kepuasan pelanggan restoran Yung Ho Surabaya. Jurnal Manajemen Pemasaran, 1(2), 1-10.

Yong, C.K., Siang, D.O.C., Lok, T.Y. \& Kuan, W.Y. (2013), Factors influencing dining experience on customer satisfaction and revisit intention among undergraduates towards fast food restaurants, (Unpublished doctoral dissertation). University Tunku Abdul Rahman, Petaling Jaya, Malaysia. 